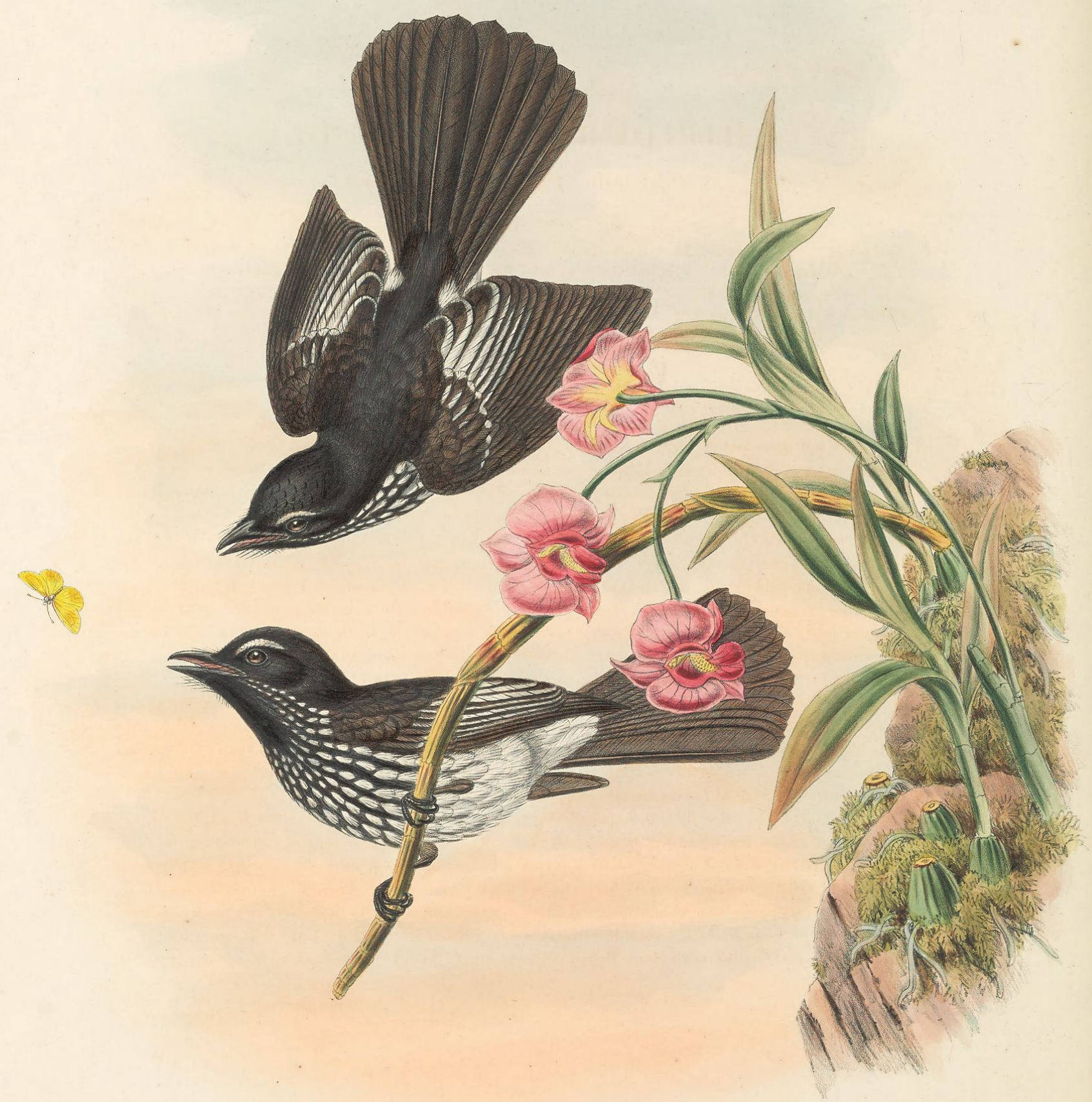

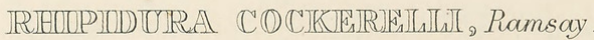




\title{
RHIPIDURA COCKERELLI.
}

\author{
Cockerell's Fantail Flycatcher.
}

\author{
Sauloprocta cockerelli, Ramsay, Proc. Linn. Soc. New South Wales, iv. p. 81 (1879).-Salvad. Ann. Mus. Civic. \\ Genova, xiv. p. 508.-Id. Ibis, 1880, p. 129.-Id. Orn. Papuasia, etc. ii. p. 53 (1881).-Id. op. cit. iii., \\ App. p. 531 (1882). \\ Rhipidura cockerelli, Ramsay, Proc. Linn. Soc. New South Wales, vi. p. 181 (1881).-Tristr. Ibis, 1882, p. 142. \\ -Ramsay, Ibis, 1882, p. 473.
}

THis species was described by Mr. Ramsay from a specimen obtained in Guadalcanar, in the Solomon group, by Mr. Cockerell. In the absence of specimens Count Salvadori was inclined to think that it might be the same species as $R$.tricolor, an identification which was rather warmly resented by Mr. Ramsay, who certainly might be supposed to know thoroughly so familiar a species as $R$. tricolor of Australia. On examining the type specimen, which Mr. Ramsay has kindly lent to us, we find that it is not of the Sauloprocta type at all, but is, as Count Salvadori has more recently suggested, a true Rhipidura as regards coloration. As, however, we cannot admit that Sauloprocta is generically distinct from Rhipidura, it follows that its position in the latter genus would be between $R$. perlata and $R$. tricolor, in the same black-throated section as the last-named bird. It may, however, be distinguished by its smaller size, by the ovate drops of white on the fore neck and chest, and by the broad white margins to the inner secondaries.

The following description is taken from the type specimen lent to us by Mr. Ramsay :-

Adult male (type of species). General colour above brownish black, the long feathers of the rump tipped with white and forming a tolerably complete band; lesser wing-coverts like the back; median and greater coverts blackish brown, narrowly edged with black, the latter with a small spot of white at the ends; bastard wing, primary-coverts, and quills blackish brown, the inner secondaries broadly margined with white, extending round the ends of the innermost; upper tail-coverts and tail-feathers blackish brown; head black, deeper than the back; over the eye a spot of silvery white; cheeks, throat, and chest black, the cheeks slightly varied with a few white tips to the feathers, the lower throat, fore neck, and chest variegated with large ovate subterminal drops of white on each feather; breast, abdomen, and under tail-coverts white, with a few blackish edgings to the breast-feathers; thighs black; axillaries blackish brown tipped with white; under wing-coverts black, with white spots at the ends of the feathers; quills dusky blackish below, browner along the edge of the inner web. Total length $6 \cdot 3$ inches, culmen $0 \cdot 6$, wing $3 \cdot 35$, tail $3 \cdot 4$, tarsus $0 \cdot 6$.

The Plate represents the adult male in two positions, drawn from the typical example. The figures are of the natural size. 


\section{$2 \mathrm{BHL}$ Biodiversity Heritage Library}

Gould, John and Sharpe, Richard Bowdler. 1884. "Rhipidura cockerelli, Cockerell's Fantail Flycatcher [PI. 28]." The birds of New Guinea and the adjacent Papuan islands : including many new species recently discovered in Australia 2(XVII), -. https://doi.org/10.5962/p.322683.

View This Item Online: https://www.biodiversitylibrary.org/item/229877

DOI: https://doi.org/10.5962/p.322683

Permalink: https://www.biodiversitylibrary.org/partpdf/322683

\section{Holding Institution}

Smithsonian Libraries

\section{Sponsored by}

Biodiversity Heritage Library

\section{Copyright \& Reuse}

Copyright Status: Public domain. The BHL considers that this work is no longer under copyright protection.

This document was created from content at the Biodiversity Heritage Library, the world's largest open access digital library for biodiversity literature and archives. Visit BHL at https://www.biodiversitylibrary.org. 